\title{
The emotions of upper secondary level students in a virtual learning environment
}

\section{Las emociones de los estudiantes del Nivel Medio Superior en un entorno virtual de aprendizaje}

\author{
FLORES-GONZÁLEZ, Efigenia†* \\ Benemérita Universidad Autónoma de Puebla
}

ID $1^{\text {st }}$ Author: Efigenia, Flores-González / ORC ID: 0000-0002-8340-9340, Researcher ID Thomson: S-5923-2018, CVU CONACYT ID: 333959

DOI: $10.35429 /$ EJT.2021.9.5.14.23

Received March 22, 2021; Accepted June 30, 2021

\begin{abstract}
In recent years and derived from the pandemic that is experienced today, online education has been advancing by leaps and bounds. It has demanded that educational actors face and adapt to a series of changes that have been generated by the implementation of digital environments in the teaching-learning process. It is in this scenario where the objective is to identify the students' emotions from High school with respect to their learning in a virtual environment. They experience a series of emotions that according to Lin, Su, Chao, Hsieh and Tsa, (2016) can generate the ideal environment to develop more successful learning processes through positive emotions. To achieve this objective, a quantitative investigation was developed, and a questionnaire with a Likert scale was designed and applied to a sample from the Enrique Cabrera Barroso Regional High School. This instrument revealed the emotions they experience in a virtual learning environment during their learning process and their interaction among the actors. Considering the results, we find that students experience a series of internal emotions that are decisive for adapting to a virtual environment.
\end{abstract}

Emotions, Virtual learning environment, Virtual learning

\begin{abstract}
Resumen
En los últimos años y derivado de la pandemia que se vive hoy en día, la educación en línea ha ido avanzando a pasos agigantados, esto ha demandado que los actores educativos se enfrenten y adapten a una serie de cambios que se han generado por la implementación de los entornos digitales en el proceso de enseñanza aprendizaje. Es en este escenario donde se tiene como objetivo identificar las emociones de los estudiantes del Nivel Medio Superior (MES), con respecto a su aprendizaje en un entorno virtual. Pues experimentan una serie de emociones que de acuerdo con Lin, Su, Chao, Hsieh y Tsa, (2016) pueden generar el ambiente idóneo para desarrollar procesos de aprendizaje más exitosos con las emociones positivas. Para alcanzar dicho objetivo, se desarrolló una investigación de corte cuantitativa, se diseñó y aplicó un cuestionario con escala tipo Likert a una población muestra de la Preparatoria Regional Enrique Cabrera Barroso. Dicho instrumento reveló las emociones que experimentan ante un entorno de aprendizaje virtual, durante su aprendizaje y su interacción entre los actores. Dentro de los hallazgos encontramos que los estudiantes experimentan una serie de emociones internas que son determinantes para adaptarse a un entorno virtual.
\end{abstract}

Emociones, Entorno virtual de aprendizaje, Aprendizaje virtual

\footnotetext{
* Author Correspondence (e-mail: florefi_ibp@ hotmail.com)

$\dagger$ Researcher contributing as first author.
} 


\section{Introduction}

Online education has grown in importance in recent years. One of the many reasons is because it promotes an education without borders, with access to anyone who wishes to appropriate the knowledge and especially for those who, due to different situations, cannot join a face-to-face education.

However, nowadays virtual learning environments have become present in a necessary and immediate way, derived from the pandemic that is being lived, to such a degree that the introduction of technology in education has transformed the face-to-face educational system and has directly impacted on the way of life of each of us who make up the educational community.

This has led all educational actors to modify or potentiate attitudes and ways of working to face the new digital scenario and adapt to innovative techno-pedagogical designs that promote meaningful learning. It is necessary to mention that according to Hernández, Fernández and Pulido (2018), said adaptation process demands the development of attitudes such as internal motivation, commitment, disposition, assertiveness and efficiency, mainly in the communication process; attitudes that are evidenced in the learning processes of students. According to the aforementioned authors, the student's willingness to start or finish an online education program will be determined by various factors, one of which is her attitudes or emotions.

For the present work and taking into account different authors (Alabdullaziz, Muhammad, Alyahya \& Gall, nd), attitudes are composed of affective, cognitive and behavioral elements that are manifested in emotions, determining elements to specify a perception of the context in the that the subject develops, and affect the like or dislike towards an action, task or object.

According to Bertea (2009), positive emotions in a virtual learning environment increase the chances that the student will accept the new teaching system, since they promote a good attitude to learn, which leads to active participation, avoiding resistance to the appropriation of knowledge (Lee \& Li, 2016).
Based on the above, the objective of this research is to identify the emotions of students in a virtual learning environment from the exploration of the reactions they experience in their teaching-learning process and their interaction with educational actors.

\section{Theoretical framework}

The key concepts to understand the phenomenon of study are described below.

\section{The role of emotions in the virtual learning process.}

For Rebollo, García, Barragán, Buzón and Vega (2008) emotions are actions learned and carried out at significant moments or opportune occasions, which are represented in the form of adaptation to the environment in which the individual develops.

According to studies by Oye, A. Iahad, Madar and Ab. Rahim, (2012), there is a relationship between emotions and academic performance of students who are in a virtual learning environment. Thus, an emotion can trigger multiple attitudes, whether positive or negative, which will be expressed through perceptions, influencing performance. For example:

- $\quad$ Alter attention and willingness to learn

- Generate positive or negative behavior patterns that favor or inhibit the learning process

- Show willingness to incorporate new knowledge

- $\quad$ Facilitate the appropriation of knowledge or,

- $\quad$ Activate relevant associative networks in memory that facilitate the learning process.

On the other hand, Saabah (2013) affirms that emotions are closely related to learning in a virtual environment, identifying a positive relationship between skills for incorporating technology and the attitude towards learning in a virtual environment.

According to Quinn (2006), there is evidence that learning improves by minimizing negative emotions and enhancing or maximizing positive ones. 


\section{Virtual learning environment}

The incorporation of information and communication technologies have evolved and have been inserted in education, generating gaps around the modalities of the teaching-learning process such as: face-to-face, mixed or virtual mediated by technological tools. However, in the last two scenarios, the teacher must necessarily use communication media to interact synchronously or asynchronously with their students as well as technological tools for the development of digital resources (Rodríguez, 2020).

Now, what is a virtual learning environment? Suarez (2002) conceives it as the application of a techno-pedagogical design with an educational intention, which regulates and transforms the interaction between educational actors, promoting forms of external action for learning and the modification of their learning strategies.

It is important to mention that initially these virtual learning environments emerged as a support tool for distance education, however today, they are used as a complement to face-toface training.

According to Cruz Benzan et al (2011), a virtual learning environment has the following characteristics:

1. Offer technological support to teachers and students to guarantee an effective teaching-learning process

2. Provide a variety of ad doc tools to the teaching model

3. Generate and allow a space for fluid and active communication between the actors in the process

4. Provide a space for students to contribute as designers and content producers.

In this order of ideas, a virtual learning environment aims to become a space that facilitates the diversification of distance, face-toface and mixed teaching modalities.
The present work is contextualized in a virtual environment. In this modality, it is considered pertinent to generate virtual learning communities that contribute to the development of emotions, where there is:

- Willingness on the part of educational actors to share and guarantee the appropriation of knowledge through the achievement of shared objectives.

- Active interaction between all actors, which promote an ideal and motivating learning environment

- Collaborative learning, which accounts for products that demonstrate learning based on established indicators

- $\quad$ Provide a socially constructed meaning that is conducive to learning for life.

In this regard, Mothibi (2015) affirms that the adequate implementation of information and communication technologies in a virtual learning environment are a triggering and effective tool to potentiate the development of students' skills.

\section{Virtual learning}

One of the characteristics of virtual learning is the physical absence of the teacher and the student, so the monitoring of the didactic materials for teaching and the performance criteria of the students do not require synchronous communication by the teacherstudent or student-student.

Boneu (2007), considers that there are 3 axes in virtual learning:

1. Interaction. Communication process between teacher-student, or studentstudent in order to build learning where emotions are observed by the actors, which influence the appropriation of knowledge.

2. Collaboration. Joint tasks mediated by technology that contribute to the development of competencies

3. Production. Evidence that reflects technology-mediated learning. 
According to Barberá, Badia and Mominó (2001, p. 164), interaction is the "set of interconnected reactions between educational actors, in which cognitive activity is developed based on the elements that determine the nature of the virtual context".

This is how in any educational process, interaction is a necessary element since it allows strengthening interpersonal relationships between educational actors and as a consequence decreases the affective distance from communication, which can generate positive emotions in the student (Alcalá, 2009).

Another characteristic of virtual learning is the design of didactic materials with which the student will interact, because the tasks are based on the principle of autonomous work. These materials should guide and motivate the student in the development and self-regulation of their own learning.

\section{Methodology}

In order to identify the emotions of students at the Upper Secondary level (NMS) in a virtual learning environment, a quantitative crosssectional study was developed since the information was collected in a single moment (Hernández, Fernández \& Baptista ( 2014) through a questionnaire with a Likert-type scale.

\section{Sample}

4 groups from the 4th semester of the Enrique Cabrera Barroso Regional High School participated, whose ages range between 16 and 17 years. Derived from the pandemic that is experienced today, they receive their classes in a $100 \%$ virtual mode.

The sample consisted of 103 students, selected under a non-probabilistic convenience sampling (Casal and Matéu, 2003).

\section{Instrument}

The Likert-type scale questionnaire is made up of three sections that inquire about emotions in different phases such as the interaction process, the learning process and the virtual modality.

The first distinguishes the emotions present in students in a virtual learning environment.
The second focuses on the learning process, a context in which emotions are presented during the construction and deconstruction of knowledge for online training.

The third aims to identify the emotions of the students during the interaction process when communicating between student-student and student-teacher.

\section{Results}

\section{Emotions present in students in a virtual learning environment}

The instrument applied for the identification of emotions experienced by students when faced with a virtual learning environment, yielded the following results.

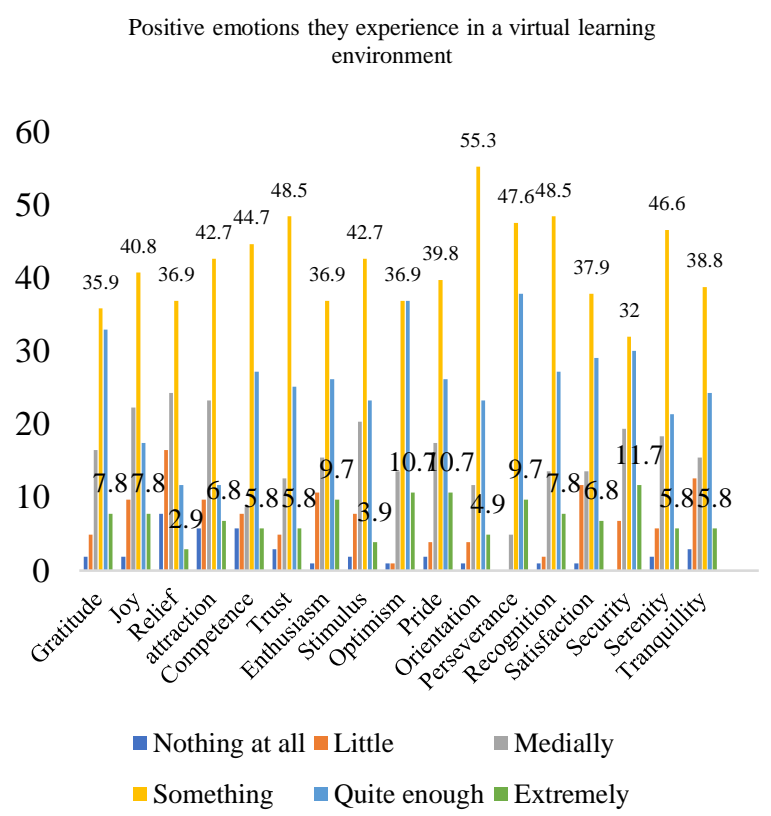

Graphic 1 Positive emotions that students experienced in a virtual learning environment. Source: Own Elaboration

In Graphic 1, the emotions of well-being that the students have experienced (a lot) are represented, among which security with $11.7 \%$, followed by optimism $10.7 \%$, pride $10.7 \%$ and enthusiasm and perseverance with $9.7 \%$.

This agrees with the investigations of Rebollar (2008) who affirms that the presence of positive emotions such as perseverance and enthusiasm are very significant in the experience of students in the virtual environment, since the learning process demands their practice for the management of one's own knowledge, the use of resources and skills for the use of technological tools. 
The emotions that they have experienced in "Nothing" are: relief with $16.5 \%$, tranquility $12.6 \%$, satisfaction $11.7 \%$, and joy and attraction $9.7 \%$, respectively. This shows that for some students it has been difficult to adapt to the virtual learning environment, so according to Cruz Benzan et al (2011) it is important to provide spaces to talk in a synchronous or asynchronous way about the difficulties they experience in the process and the achievement of the objectives.

The highest percentages are found in the indicator "Something" and these emotions are orientation with $55.3 \%$, confidence and recognition $48.5 \%$, perseverance $47.6 \%$ and serenity $46.6 \%$.

Therefore, the strong presence of orientation, confidence, optimism and perseverance agree with the studies carried out by Barragán et al (2007) who affirm that these emotions are the reflection of the emotional competence promoted by the teacher in a virtual online environment. , based on a flexible and purposeful techno-pedagogical design (FloresGonzález, 2020).

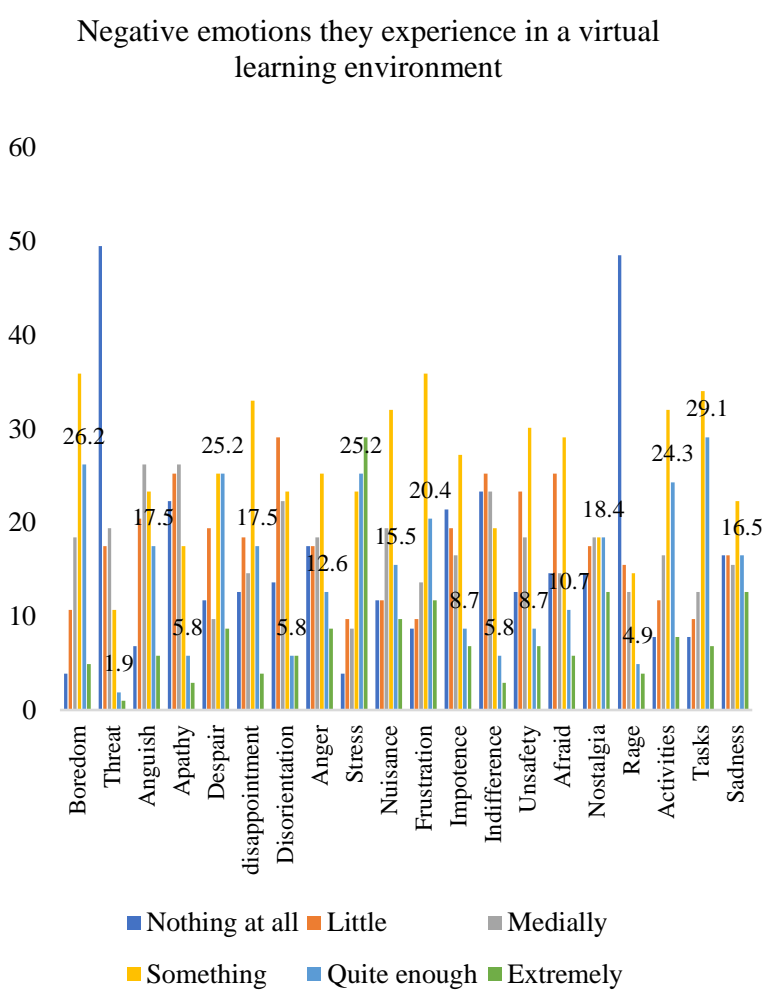

Graphic 2 Negative emotions that students experience in a virtual learning environment.

Source: Own Elaboration
It is important to emphasize that negative emotions have manifested in a lower percentage, however, as seen in Graphic 2, students have experienced "a lot" of stress with $29.1 \%$, nostalgia $12.6 \%$, sadness $12.6 \%$ and frustration $11.7 \%$. These emotions are also expressed and are closely related to the interaction between student-teacher and student-student, as will be seen later.

In contrast, $49.5 \%$ of the students have experienced "Nothing" of Threat (48.5\%), anger $(23.3 \%)$, indifference $(22.3 \%)$, apathy and helplessness $(21.4 \%)$. These results reflect the commitment of educational actors, and the purpose of the virtual space, such as regulating and transforming the interaction between educational actors promoting forms of external action for learning and modifying their learning strategies, through the application of a technopedagogical design (Suarez, 2002).

Of the negative emotions that they have experienced in the criterion "Something" and that in fact correspond to the highest percentages are: frustration and boredom with $35.9 \%$, task saturation 34\%, disappointment $33 \%$ and annoyance $32 \%$. These emotions coincide with Jarvis (2006) who affirms that frustration generates a cognitive imbalance and awakens the desire to learn.

\section{Emotions during the construction and deconstruction of knowledge in a virtual environment}

In the teaching-learning process, students incorporate new knowledge to generate a more elaborate idea and it is in this deconstruction process that they experience a series of emotions. 
Positive emotions in the construction and deconstruction of knowledge in a virtual environment

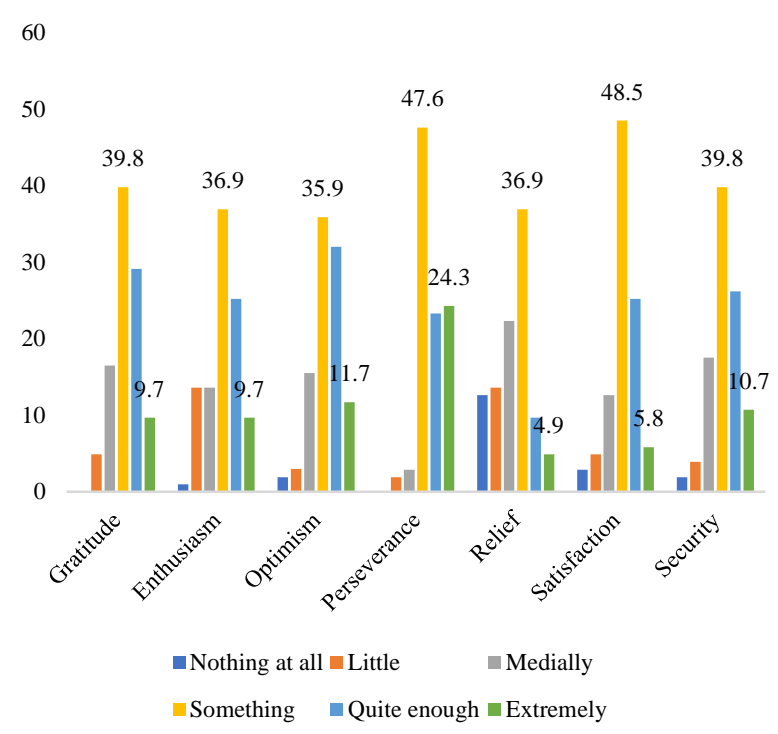

Graphic 3 Positive emotions that students experience during the construction and deconstruction of their knowledge in a virtual learning environment

Source: Own Elaboration

Graphic 3 shows the emotions that generate well-being for the student. With a higher percentage in the indicator "Something" is satisfaction $(48.5 \%)$, perseverance $(47.6 \%)$, security and gratitude $(39.8 \%)$. On the other hand, the emotions that have not experienced (Nothing) are: relief $16.5 \%$, tranquility $12.6 \%$, satisfaction $11.7 \%$ and enthusiasm with $10.7 \%$.

In this regard, Pekrum (2005) emphasizes that the relationship between reactions (evidenced by emotions of satisfaction, perseverance, security) and learning are not simple as they are regulated by cumulative factors. However, it is important to identify them, as they create a radius of opportunity to implement communication scenarios and teaching intervention.

The emotions that they experienced a lot are security $(11.7 \%)$, optimism and pride $(10.7 \%)$, enthusiasm and perseverance $(9.7 \%)$, positive attitudes that they contribute to the students' work. are described.

In the following lines, negative emotions

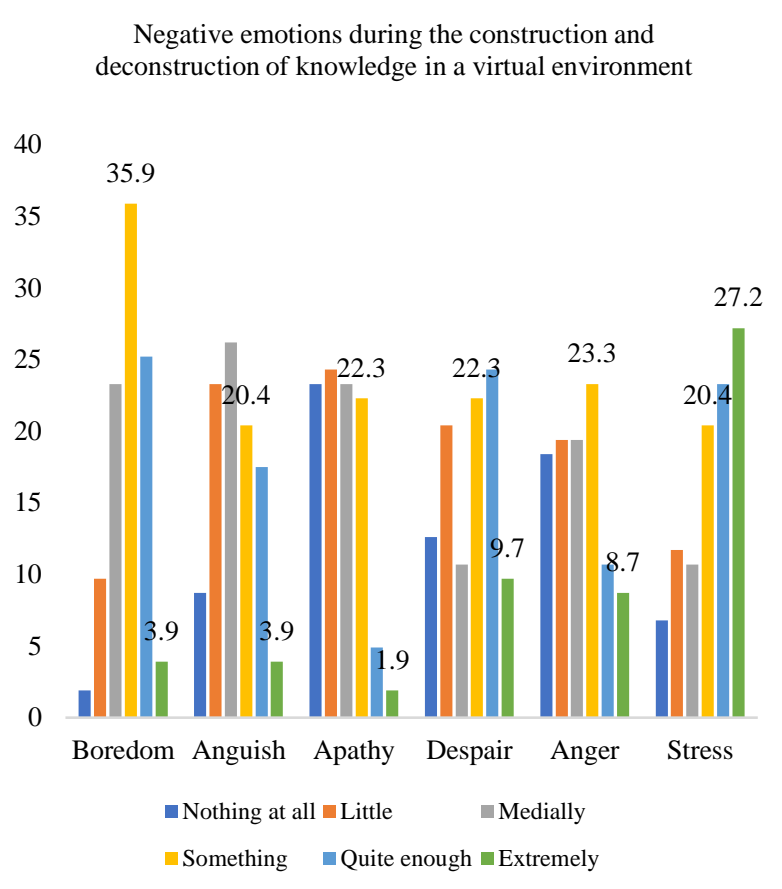

Graphic 4 Negative emotions that students experienced during the construction and deconstruction of their knowledge in a virtual learning environment

Source: Own Elaboration

As can be seen in Graphic 4, the negative emotions that experienced a lot during the construction and deconstruction of knowledge in a virtual environment are: stress (27.2\%), despair $(9.7 \%)$, anger $(8.7 \%)$, boredom and anguish ( $3.9 \%)$.

However, the emotions they did not experience are apathy (23.3\%), anger (18.4\%), despair $(12.6 \%)$ and anguish $(8.7 \%)$.

The emotions they perceived in something were boredom (35.9\%), apathy, anger and despair $(23.3 \%)$.

These results indicate that there is a relationship of emotions that emanate from stress, such as despair, anguish and anger. Others indicate motivation through emotions such as security, satisfaction, perseverance and optimism which contribute to learning. In this regard, Jarvis (2006) and Phelps (2006) point out that the degree of despair in relation to the construction of knowledge is essential to promote the desire to learn and keep the student alert to new information.

In order to complement the study, the students were asked how did they perceive their learning in a virtual environment? 
Their learning, in the virtual modality is

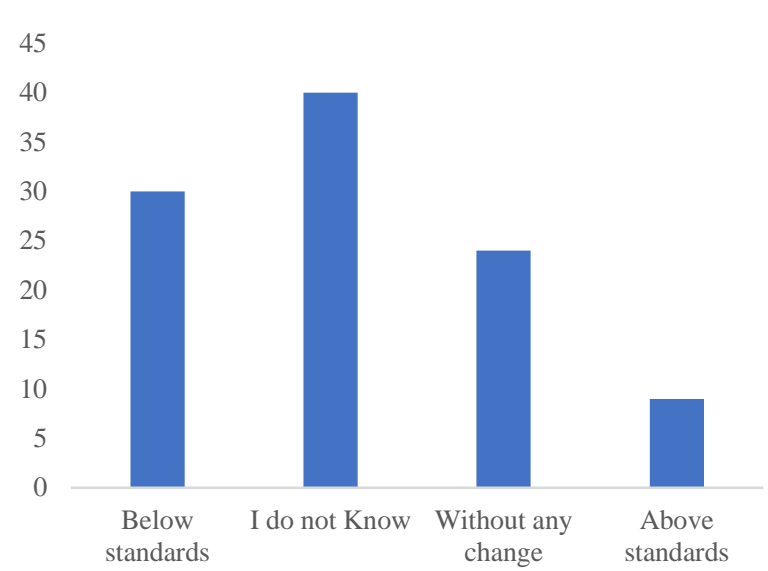

Graphic 5 Students' perception of their learning in virtual mode

Source: Own Elaboration

$39 \%$ answered I do not know, while $29 \%$ consider that it is less and $23 \%$ that it is the same. Only $9 \%$ consider that it is greater as shown in the Graphic. It is imminent that the reflectionoriented interaction to make a judgment regarding the virtual learning process is associated with various positive emotions such as perseverance, satisfaction, optimism and enthusiasm.

\section{Student emotions during the interaction process when communicating}

According to Alcalá (2009), in a virtual learning environment the communication that is established through the interaction between student-teacher and student-student, is decisive for the achievement of objectives set in an educational program and depends directly on the emotions.

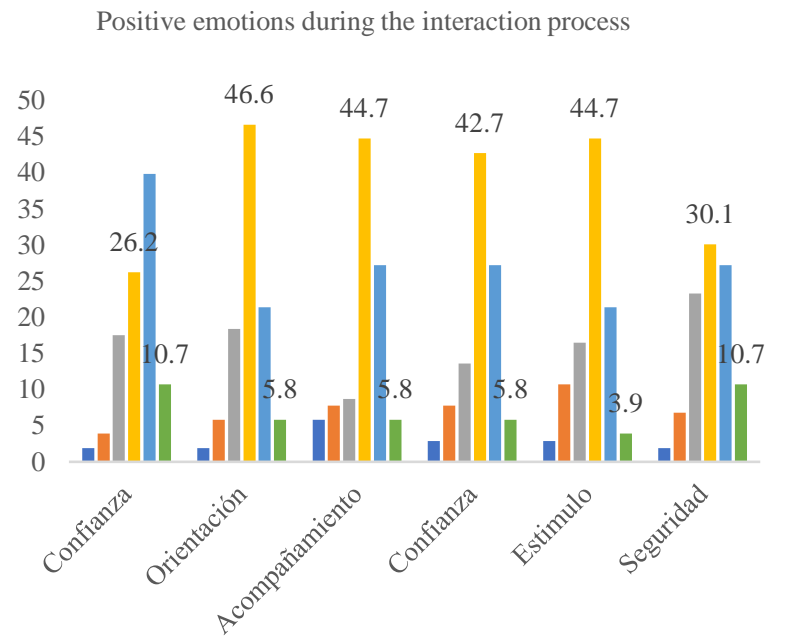

ఐ Nada $\square$ Muy poco $\square$ Poco $\square$ Algo $\square$ Bastante $\square$ Muchísimo

Graphic 6 Positive emotions that students experienced during the interaction process Source: Own Elaboration
The interaction generates a series of emotions that can facilitate or inhibit the learning process. Positive emotions are captured in this Graphic. In the first instance, the students had some guidance (46.6\%), support and encouragement (44.7\%), and confidence (42.7\%). With a lower percentage, they felt a lot of security and confidence (10.7\%) as well as a stimulus for learning $(3.9 \%)$

In contrast, $5.89 \%$ of the subjects did not perceive support, trust and encouragement (2.9\%). From these results we can identify good communication between the actors of the curriculum, which generates emotions such as accompaniment, encouragement and trust, which corroborates the role of a virtual environment, minimizing the gap between the student and the teacher to favor their interaction through communication (Cenich and Santos, 2005).

In addition to the above, Barberá, Badia and Mominó (2001) confirm that interaction can facilitate or inhibit the learning process in a virtual context where communication and interaction promote the development of interpersonal relationships that facilitate learning and group integration from the formulation of common objectives and learning networks (Suarez, 2004; Ortíz, 2005). On the other hand, the negative attitudes obtained in this section are closely related to the negative emotions experienced during the construction and deconstruction of knowledge in a virtual environment.

Negative emotions during the interaction process

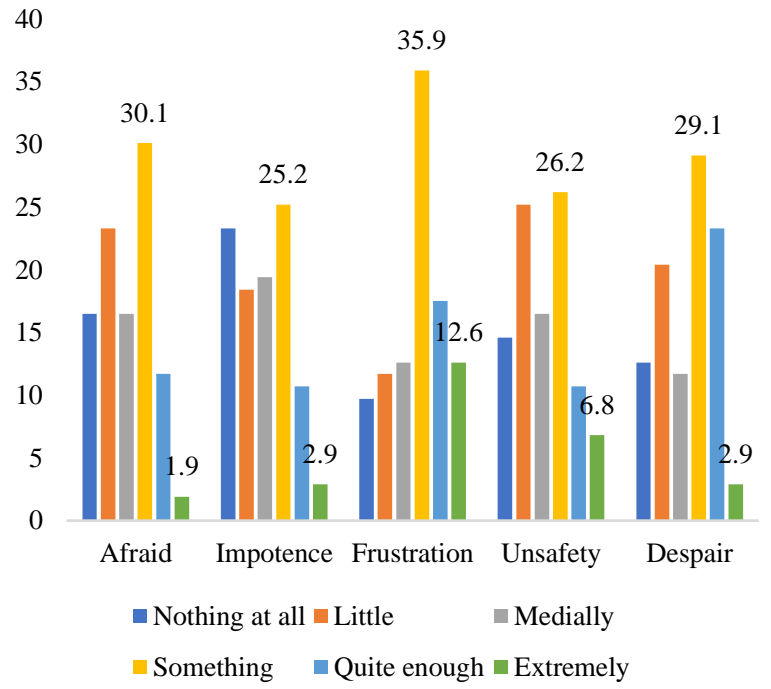

Graphic 7 Negative emotions that students experienced during the interaction process.

Source: Own Elaboration 
Graphic 7 shows that $12.6 \%$ state that they have experienced a lot of frustration, $6.8 \%$ insecurity, $2.9 \%$ despair and helplessness. This corroborates what was pointed out by Antonopoulou and Gabriel (2001), Askham, (2001), who affirm that insecurity and despair can manifest themselves in the learning process as a consequence associated with the appropriation of new knowledge, the competences that it possesses to carry out a task and the experiences of discomfort they have had. Additionally, $35.9 \%$ experienced some frustration, $30.1 \%$ fear, and $29.1 \%$ despair.

In this regard, Askhan (2001); Short and Yorks (2002) consider that these emotions, together with those experienced in the virtual environment such as security, optimism, enthusiasm, are elements that affect the virtual teaching-learning process, since they facilitate learning.

The feelings they did not express were helplessness (23.3\%), fear (16.5\%) and insecurity (12.6\%).

\section{Conclusions}

From the findings, it is inferred that the students' responses are regulated by the internal emotions they experience, because when feeling stress, it will be very difficult to express enthusiasm and perseverance to interact not only with the educational actors but also with the contents, despite the fact that the subject is interesting. However, if the emotions are self-regulating and express feelings such as security, optimism, orientation, trust and support, students will be able to put their emotional competences into practice and will be able to face the changes generated in their educational context without being carried away by attitudes that hinder your learning process.

Regarding the emotions they experience in a virtual learning environment, the students identified elements that generated emotions such as orientation, trust, security and recognition. In this sense, it is emphasized that orientation goes hand in hand with monitoring, which is carried out by the teacher in a synchronous or asynchronous way and is recognized by the student as an action that generates security and enthusiasm in their learning process.
With regard to emotions during the construction and deconstruction of knowledge in a virtual environment, it is found that positive emotions such as satisfaction, perseverance, security and optimism are representative, guaranteeing the willingness to incorporate new knowledge and achieve the purpose established in a program study. A close relationship was also identified between the negative emotions that students experience in their training through a virtual space, the deconstruction of their learning and the interaction between educational actors, since they express feelings of greater stress by reducing said interaction.

In addition, in the process of interaction mediated by communication, the fundamental elements in a virtual environment denote affective relationships such as support, trust, security, promoting a collective integration of new knowledge and learning. On the other hand, positive emotions generate empathy in a virtual learning environment, reducing negative emotions and increasing the desire to learn, creating an ideal environment for the achievement of common goals.

Finally, there are other situations that do not depend directly on the educational actors, and that trigger a series of emotions; however, the student can learn to react assertively and in a timely manner.

\section{References}

Alabdullaziz, F., Muhammad, M., Alyahya, S., \& Gall, J. (s.f.). Instructors' and learners'attitude toward e-learning within a college education. Department of Educational Technology. University of Northern Colorado. Recuperado de http://files.eric.ed.gov/fulltext/ED528860.pd

Alcalá, M. D. S. P. (2009). La comunicación y la interacción en contextos virtuales de aprendizaje. Apertura, 1(1).

Antonacapoulou, Elena y Gabriel, John (2001), "Emotion, learning and organizational change: towards an integration of psychoanalytic and other perspectives", Journal of Organizational Change Management, 14 (5), 435-51.

Askham, Philips (2001). The feeling's mutual: excitement, dread and trust in adult learning and teaching, $\mathrm{PhD}$ dissertation, Education Department, Sheffield Hallam University, Sheffield.

FLORES-GONZÁLEZ, Efigenia. The emotions of upper secondary level students in a virtual learning environment. ECORFAN Journal-Taiwan. 2021 
Barberá, E. (coord.), Badia, A. y Mominó, J. Ma. (2001), La incógnita de la educación a distancia, Cuadernos de Educación, núm. 35, España, Horsori.

Barragán, Raquel; Buzón, Olga y García Pérez, Rafael (2007). Diagnóstico y evaluación de aprendizajes universitarios con portafolios: regulación de aprendizajes Blended-Learning y nuevos roles del alumnado. En Felipa Etxeberría, Lander Sarasola, José Francisco Lukas, Juan Etxeberría y Aitor Martxueta (Coords.). Actas del XIII Congreso Nacional de Modelos de Investigación Educativa, AIDIPE: San Sebastián, 958-964.

Bertea, P. (2009). Measuring student's attitudes towards e-learning. A case study. Conferencie Proceedings of E-learning and Software in Education, (1), 417-424. Recuperado de https://www.ceeol.com/content-files/document37597.pdf

Boneu, J. (2007) Plataformas abiertas de elearning para el soporte de contenidos educativos abiertos. Revista de Universidad y Sociedad de Conocimiento, 4(1). Recuperado el 18.06.2021 desde https://bit.ly/2Sh0Xcy

Casal, J., \& Mateu, E. (2003). Tipos de muestreo. Rev. Epidem. Med. Prev, 1, 3-7. Recuperado de http://www.mat.uson.mx/ ftapia/Lecturas\%20 Adicionales $\% 20$

(Cómo\%20diseñar\%20una\%20encuesta)/Tipos Muestreo1.pdf

Cenich, G. y Santos, G. (2005), "Propuesta de aprendizaje basado en proyecto $\mathrm{y}$ trabajo colaborativo: experiencia de un curso en línea", Revista Electrónica de Investigación Educativa, vol. 7, núm. 2: Fecha de consulta: 18 de abril de 2007.

http://redie.uabc.mx/vol7no2/contenidocenich.h tml\#Instancias\%20de\%20interacción\%20social

Cruz Benzan, M. Hiraldo, R. y Estrada, V. (2011). El aprendizaje virtual y la Gestión del Conocimiento. Estudio de Caso de la Universidad Abierta para Adultos, UAPA, República Dominicana. México. Revista de Educación a Distancia. No. 208. IESALCUNESCO.
Flores-González, N. (2020). Authenticinteractive activities to promote oral production on a virtual platform. Journal of Applied Computing. 4 (15), 26-35.

Hernández Godoy, V. L., Fernandez Morales, K., \& Pulido, J. E. (2018). La actitud hacia la educación en línea en estudiantes universitarios. Revista de Investigación Educativa, 36(2), 349364. https://doi.org/10.6018/rie.36.2.277451

Hernández, R., Fernández, C., \& Baptista, M. (2014). Metodología de la Investigación. Recuperado de https://trabajosocialudocpno.files.wordpress.co m/2017/07/metodologc3a3c2ada_de_la_investi gacic3a3c2b3n_-sampieri-_6ta_edicion1.pdf

Jarvis, Petter. (2006), Towards a Comprehensive Theory of Human Learning: Lifelong Learning and the Learning Society, Routledge, London

Lee, L., \& Li, L. (2016). Computer literacy and online learning attitude toward GSOE students in distance education programs. Higher Education Studies, 6(3), 147-156. Recuperado de

http://www.ccsenet.org/journal/index.php/hes/a rticle/viewFile /61435/33419

Lin H., Su S., Chao C., Hsieh C., Tsai S. (2016). Construction of Multi-mode Affective Learning System: Taking Affective Design as an Example. Educational Technology \& Society, 19(2), 132-147.

Mothibi, G. (2015). A meta- analysis of the relationship between e-learning and student's academic achievement in higher education. Journal of Education and Practice, 6(9), 6-9. Recuperado http://files.eric.ed.gov/fulltext/EJ1082408.pdf

Ortiz, A. (2005), "Interacción y TIC en la docencia universitaria", Píxel-Bit, núm. 26: Fecha de consulta: 14 de abril de 2007. http://www.sav.us.es/pixelbit/articulos/n24/n24 art/art2401.htm

Oye, N., A.Iahad., N., Madar, M., \& Ab.Rahim, N., (2012). The Impact of e-learning on students' performance in tertiary institutions. International Journal of Computer Networks and Wireless Communications. 2(2), 121-130. Recuperado de http://www.

ijcnwc.org/papers/vol2no22012/2vol2no2.pdf 
Pekrun, Reinhard (2005). Progress and open problems in educational emotion research. Learning and Instruction, 15, 497-506

Phelps, Edwards (2006), "Emotion and cognition: insights from studies of the humanamygdala", Annual Review of Psychology, 57, (2)27-53.

Quinn, C. (2006). Making It Matter to the Learner: e-Motional e-Learning

Rebollo Catalán, Mª A., García Pérez, R., Barragán Sánchez, R., Buzón García, O. y Vega Caro, L. (2008). Las emociones en el aprendizaje online. RELIEVE, v. 14, n. 1, p. 1-23. http://www.uv.es/RELIEVE/v14n1/RELIEVEv 14n1_2.htm

Rodríguez, M. R. (2020). Rol del docente y estudiante en la educación virtual. Revista Multi-Ensayos, 6(12), 28-37.

Saabah, N. (2013). Students' attitude and motivation towards e-learning. Presentado en el The First International Conference on Applied Sciences, Gaza-Palestine Recuperado de http://www.academia.edu/4765736/Students_At titude_and_Motivation_Towards_E-learning

Short, Claus y Yorks, Leiden. (2002), "Analysing training from an emotions perspective", Advances in Developing Human Resources, 4 (1), 80-96.

Suarez Guerrero, (2002). Los Entornos Virtuales de Aprendizaje como Instrumento de mediación. Ediciones Universidad de Salamanca. España.

Suárez, C. (2004), "La zona de desarrollo próximo, categoría pedagógica para el análisis de la interacción en contextos de virtualidad", Píxel-Bit, Revista de Medios y Comunicación, núm. 24: Fecha de consulta: 14 de abril de 2007. http://www.sav.us.es/pixelbit/articulos/n24/n24 art/art2401.htm 